\title{
Gestalt Therapy Approach to Depressive Experiences'
}

\author{
Gianni Francesetti \& Jan Roubal
}

\author{
Psychotherapie-Wissenschaft 10 (2) 39-45 2020 \\ www.psychotherapie-wissenschaft.info \\ CC BY-NC-ND \\ https://doi.org/10.30820/1664-9583-2020-2-39
}

\begin{abstract}
Mourning and depressive experience are distinguished to highlight the core of the suffering of people in depression. In the mourning experience a specific person or situation becomes unreachable and therein lies the loss suffered. The experience of melancholic depression differs: what is lost is that which anchors the subject to the fabric which connects $\mathrm{him} /$ her to the world. A radically relational approach to depression where the client and therapist are seen as depressing here and now in the therapy's situation is introduced.
\end{abstract}

Key words: Gestalt therapy, depression, grief, psychopathology, self-functions

«Hell is where nothing connects.» T.S. Eliot

\section{A brief diagnostic consideration}

According to the World Health Organisation, depression affects hundreds of millions of people worldwide and it is a very common experience among the psychotherapists' clients. At least $20 \%$ of women and $12 \%$ of men experience depression during their life and $15 \%$ of depressed people end their life by suicide (Akiskal, 2000). The use of the term «depression» (from Latin, meaning downwards pressure) in psychiatry to describe a state of low mood began at the end of the nineteenth century. Previously, such phenomena were diagnosed as melancholia. According to psychiatric diagnostic systems (DSM-IV, ICD-10) the depressed person suffers a mood disorder characterised by low mood, decrease of energy and activity, reduced ability to feel pleasure, poor concentration and increased tiredness. The depth of depression is measured according to a list of criteria. The term «depression» is used to refer to a wide range of experiences which vary in seriousness and which may also represent a natural response to significant life transitions. The exponential increase of diagnosis of depression and of prescription of antidepressant is - partially - the result of a big diagnostic problem of this part of the nosographic systems: many so called depressions are reaction to losses and situations of stress, and they receive a diagnosis and a treatment as if they were depressive experiences. Also the hot debate on the efficacy of antidepressants should be understood in the light of the diagnosis: if the medicaments are prescribed to a sample of people that is not constituted by patients really suffering from depression, of course the results cannot be better than a placebo. Indeed, research on drugs' efficacy must be based on a clear and careful diagnostic assessment. In our experience, the antidepressants must be considered in the melancholic depression (and not to take them in consideration in such situations is malpractice); but shouldn't be used just because the client has a low mood following to a loss (to use them without further considerations in such situations is again malpractice). So it is crucial to distinguish - at least - between a condition that is a reaction to a loss (like the grieving process) and a condition that we can call melancholic depression. We refer the reader to the references in footnote 1 for widening this topic.

\section{Depressive Experiences: a Gestalt Approach}

We will now seek to frame the depressive experience within a meaningful frame originating from a phenomenological-Gestalt perspective ${ }^{2}$ (Roubal, 2007; Francesetti \& Gecele, 2009, 2011). We will focus on how the patient and the therapist together are affected by a depressive field. Although we sometimes (for communication reasons) use the expression that «the patient is depressed», our basic attitude is always field based, we keep in mind that the patient and the therapist are hereand-now depressing together as an effect of the forces of the phenomenal field (Francesetti, 2019a, b; Francesetti \& Roubal, forthcoming). In order to orient the work in therapy one basic distinction must be done between the reaction to a loss and the melancholic experience.

1 This article comes from our chapter in Francesetti et al. (2013). We refer to it for a further reading and to Francesetti (2014).

2 See Galimberti (1987, 2003); Borgna (1988, 1992, 1994, 2008); Blankenburg (1971); Kimura (2000, 2005); Callieri (2001); Rossi Monti (2002); Minkowski (1933); Binswanger (1960); Stanghellini (2006); Maldiney (1991); Gozzetti (2008); Salonia (1989, 2001a, b, 2005, 2008, 2010); Melnick \& Nevis (1998); Greenberg et al. (1998); Amendt-Lyon (1999); Spagnuolo Lobb (2001a, b, 2005, 2007); Staemmler (2004); Vázquez Bandín (2005); Van Baalen (2010); Bloom (in preparation). 


\section{Mourning: the Presence of the Absence}

We must differentiate between sadness (as an expression of mourning) and depression. This differentiation can be found already in the early psychoanalytical work of Abraham and then of Freud (1925 [1917]) in his classic article «Mourning and Melancholy». The experiences of depression and of sadness can both show similar symptoms but in practice it is very important to differentiate between them. To work psychotherapeutically with depression and sadness using the same approach can even harm the patient (Smith, 1985). Mourning is a way of assimilating important loss. Here we focus on bereavement, similar experience can be observed with other kinds of important life events containing loss, like abortion, dismissal, refugeeism etc. The assimilation process required is analogous to that required in cases of bereavement.

Mourning helps the individual to assimilate not only the loss suffered, but also her/his relational experience with the lost one. One of the gifts which death gives us is its revelation of the beauty of the one who has gone. His/her absence reveals the depth and worth of his/her presence. The negative side of this for those who remain is the discovery of their own absences in the presence of the loved one: "Why didn't I realise how important, wonderful and rich it was to be with him/her?» The mourning period serves to establish a double loyalty: to the relationship which has been lost and to life which must go on. When this double loyalty has been attained, the mourning period comes to an end (at least for that specific period of life). Mourning enables life to preserve the wealth to be derived from the past relationship (Cavaleri, 2007) and to launch itself once more into the ever-springing fount of the new.

Whilst in the immediate wake of a bereavement, the unattainability tends to dominate the foreground, with time memories beginning to surface, the awareness of having-been-with the lost one and of all that you have experienced together. In this way, the experience of the relationship is assimilated and the subject gradually attains a state of presence in absence. The remaining one learns to carry the lost one with him/her, developing a new capacity of «being-with» the other and a new form of fidelity.

Mourning is essentially a period of assimilation, of post-contact. It is a stage of the contact sequence whereby the other is no longer present to the senses. Yet it is not a purely reflective phenomenon. The senses are acutely involved, because it is through the senses that the loved one's absence is perceived. In mourning, I am with the other in the very impossibility of reaching him/her: I am fully in the presence of his/her absence. Mourning is therefore a necessary and creative period, which enables me to assimilate who I became with the one I have lost and who I am to become without him/her.

\section{Melancholic Experience: the Absence of the Presence}

Melancholic (endogenous or psychotic) depression, generally unrelated directly to events in the patient's life (but they might be important as triggers), represents an extreme form of depressive experience where qualitatively new phenomena can appear. ${ }^{3}$ The person experiences not so much just a sense of despondency, rather a continuous physical heaviness: "As if there were a stone constantly pressing down on my thorax." "It's as if it were squeezing all the life out of me.» S/he may experience a lack of any kind of sentiment, a sensation of numbness, of being stranded in an emotional wasteland. The body is de-sensitised, often feeling heavy or empty. The person experiences a lack of energy, which can lead psycho-motor functions to slow down to the point of immobile stupor. There is a loss of appetites. The person wakes up unnecessarily early in the morning. S/he can contemplate suicide and may become delirious, with delusions usually involving guilt, ruin or hypochondria.

The personality function also undergoes alterations, ranging from simply not feeling up to fulfilling one's normal roles to a grave loss of identity. The resulting impairment is such that the person is unable to function professionally and socially and to fulfil parental and family responsibilities. "I am holding your hand merely because I know we used to do it. But I experience just emptiness.» The person comes to lack the capacity to take decisions, to lack lucidity, ambition and responsibility. Personal history may be twisted, even to the extent of deludedly «reconstructing» past faults which have no foundation in reality. In the face of such a profound dysfunction of the id and personality functions of the self, the ego function may be completely vanquished. If it cannot coexist with the id function, there can be no identification with or alienation from elements in the field and therefore no choice.

Remission after an episode (which may have gone on for weeks, months, or, without suitable therapy, years) is usually complete, and patients describe their melancholic experiences as a living nightmare, as another dimension, so far removed from their normal life that it becomes hard to remember it clearly. Episodes can recur throughout the individual's life, in some cases in alternation with manic periods. There may also be situations in which melancholy is mingled with euphoria. The prognosis with regard to any single episode is relatively good, since these frequently end in complete remission. However, we always remain uncertain as to whether and how often symptoms will recur. A milder chronic depressive state can also develop in some cases.

\section{The Self and its Functions in Melancholic Experience}

In the mourning experience a specific person or objective becomes unreachable and therein lies the loss suffered. The experience of melancholic depression differs: what is lost is that which anchors the subject to the fabric which connects him/her to the world. In the former case, one

3 Some specific (psychotic) phenomena appear in the case of melancholy. We can imagine the continuum of depressive experiences as water that becomes colder and colder and then at some point becomes ice. 
loses the other to whom one is attached, in the latter one loses the conditions which make it possible to form such a tie. ${ }^{4}$ This experience of melancholic depression presents an extreme form of a continuum of depressive experiences and as such it offers us a possibility of understanding the dynamics of the depressive experience. The more serious the case of depression, the more evident this becomes.

The gravity of a patient's depression can be measured in terms of their detachment from the in-between, of the degree to which they are absent from the contact boundary. The in-between is the common ground which we constantly co-create at the contact boundary. It is the fabric which connects us to the world and to life moment by moment. In cases of melancholy, this common ground has ceased to exist and can therefore no longer be traversed. Herein lies the unique quality of melancholic experience. The in-between is no longer a meeting place. It has instead come to represent an insurmountable cosmic abyss. In such a condition the ego function is potentially reduced to nothing, to a state of stupor in which nothing happens. The id function (the pre-reflexive function which connects us to the world prior to the rift between the self and the world, the organism and the environment), instead assumes a more significant role. It is a disorder of the id of the situation (Robine, 2011), where the very fount of subjectivity, time, space and intentionality - life itself - are generated.

The profound dysfunction of the id function means that it is impossible to co-create a figure of contact. This dysfunction lies at the heart of the therapist's difficulty in connecting with the patient, in ensuring the usual comings and goings of resonances, consonances and dissonances which should fill up therapeutic space and time. In short, nothing reverberates in the therapeutic in-between. A central facet of depressive experiences is the lack of any interest. This does not simply mean that the subject is not attracted to or involved in anything. It also has the more radical implication that $\mathrm{s} / \mathrm{he}$ is no longer in the «inter» of «esse», that s/he in some sense is removed from being in the in-between itself, from the nerve centre where all the infinite strands of life knit together (Bonani, 2009). The sense of lifelessness, which is perhaps one of the most distinguishing features of depression, is clearly a manifestation of this condition. The healthy growth of the self requires that the organism be at once separated from and welded to the world. This connection with the world is what is lacking in melancholic experience, whilst in cases of schizophrenic experience it is the development of separation and boundaries which is lacking (Francesetti, 2011, 2014). The depressive experience is expression of a relational field. Time and space are the roads which we conceive of ourselves as we make our way towards that which is loved and necessary. They are relational-dependent variables, generated through the impetus of the journey itself, which is never just a

4 We here diverge from the psychoanalytic perspective, which suggests that melancholy consists in the unconscious loss of an object which is transferred to the ego - and herein lies its difference from mourning, where loss is transferred to the outside world (Freud, 1925 [1917]). single movement but always a co-movement. When this movement fails, what we experience is the abyss which separates us. The affective bridge, upon which our very selves are constituted and from which subjectivity springs, is lost. Depressive experiences are the expression in the individual of a specific relational experience: namely the impossibility of reaching the other. To be more specific: depression is the way in which the subject experiences the surrendering of hope in the face of the ineffectiveness of his/her vain attempts to reach the other. Depression can be understood as a co-constructed relational phenomenon with three intrinsic and essential features: a profound attachment, whereby the other is loved and necessary, the failure of all efforts to reach the other and the emotive absence of the other from the relationship.

\section{The Experience of the Therapist}

The usual organisation of the relational field tends to repeat in the therapeutic situation too. The therapist becomes a part of the «depressive organisation» of the field.

The usual reaction of the patient's family or other nearest and dearest persons to her/his depressive state is polar. They first want to encourage her/him: «Come on, it will be OK soon. Let's have some fun, It will help you to overcome this.» Later, when this effort is not effective and they become exhausted, they try to protect themselves and withdraw from the depressed person (often with more or less hidden aggression).

The therapist finds her/himself in the same relation pattern and s/he feels impulses to repeat the described reactions to the depressive person. Thanks to her/his awareness the therapist has the chance to step out of this rigid relational pattern and respond differently to the depressed person $-\mathrm{s} / \mathrm{he}$ remains available for contact, does not blame either her/himself or the patient, does not give up hope. Doing this, the therapist changes the usual rigid field organisation and opens a space for a change also for her/his patient.

Fear is a common initial reaction when dealing with a severely depressed patient. This may take the form of an undefined yet powerful sense of unease or of an intense fear for the patient. Sometimes the therapist may wish to get away from the patient, or to send him/her on to be dealt with by someone else. It is important to frame these experiences in their field context. All of these reactions reflect the therapist's perception of the lack of ground in the relational field. It is for this reason that the involvement of a third party provides a vital anchor (Francesetti \& Gecele, 2009, 2010). This may take the form of pharmacological support, supervision, meetings with colleagues or further theoretical training (hopefully including reading this article).

Another aspect of countertransference concerns the side effects of the therapist's placing him/herself in a depressive field. The depressive condition leaves the therapist teetering on the edge of a precipice, feeling a terrible weight pulling him/her down towards into the 
abyss, the vacuum, a state of solitude, fear and extreme impotence where all sense of direction is lacking. This can lead to feelings of anger, which may result in self-depreciation ("I'm not up to working with this patient») or a loss of faith in one's training and profession ( $« M y$ chosen therapeutic approach doesn't equip me to deal with this patient» or "Psychotherapy's no use at all with this patient: [s] he just needs medication!»).

The experiences of a therapist with a depressive patient can be described by an overall metaphor of «magnetic power of depression» (Roubal, 2010). The therapist feels drawn to the patient experience as to a magnet. S/he then either keeps a safe emotional distance by keeping a professional mask, keeping the depressive experience unfamiliar for her/himself and sometimes taking an inappropriate responsibility for the whole situation. Or, the therapist comes closer by sharing the patient's depressive experience to some extent. The therapist experiences falling off, loneliness, helplessness, shame, heaviness. In this case s/he might feel endangered by the risk of «depressive contagion», s/he experiences: «It is too much for me!» and reacts by self-protection and/or aggression towards the patient: "She's unbearable. She needs me and I'm here, holding out my hand but she just can't see it!» or «Nothing I do is of any use, so she can do as she likes and that's that!» The therapist may feel tempted to defy or challenge the patient: "Ok then, let's see what's stronger: my commitment or your inertia!»

It is important for the therapist to be aware of her/his own experience and not to blame her/his patient or her/himself for it, because blaming is a distinct feature of a depressive field organization. The therapist can use the metaphor of «magnetic power of depression» and her/his experience would indicate how strong the «magnetic power» of depression is and what is the therapist's position towards it.

The therapist her/himself is endangered in the depressive field organisation. S/he might get «infected» by the patient's depression and get depressed too. There is a clinically observed phenomenon of spreading emotions associated with depression in interpersonal contacts. The "contagiousness of depression» is a theoretical concept that serves as a tool for better understanding and not for blaming the «carrier» of the depression. This concept has been substantiated by meta-analysis of 40 research projects (Joiner \& Katz, 1999) which gives sufficient support to the statement: «depressive symptoms are contagious in close relationships». ${ }^{5}$

The therapist's task is to remain present, when it would be so easy to get lost, fall asleep or lose one's temper, without getting depressed, when it is so easy to lose hope. Such a situation represents one of the most arduous tasks faced by the psychotherapist: $\mathrm{s} / \mathrm{he}$ places her/his own self at the patient's disposition, but in this situation his/her id function encounters an abyss. How can s/he inhabit such a cavity, such an abyss?

5 There are different hypothesis explaining the mechanisms, e.g. excessive searching for support; excessive self-disclosure; emotional transference; burden; assortative mating; attribution theory, common history; self-verification theory; imitation.
All the therapist's experiences should be brought into awareness, because they represent a way of being-with the other in the relational field. The field perspective provides support to the therapist on two counts: it enables him/ her to make sense of his/her emotions at the same time as enabling him/her to act. By simply asking her/himself "how are we depressing together now?" the therapist brings the situation back into range.

\section{Suggested Therapeutic Approach ${ }^{6}$}

Depressive experience is like a swamp for both the patient and the therapist. It is useless to jump in a swamp, to have ambitious therapeutic goals, to push for optimism. The more the therapist encourages the patient to jump, the more the patient sinks. Instead, slow, little movements that patiently look for minor sources of support are needed. The therapist does not force introspection of the patient, does not look for what is not working. This retroflective and self-critical pattern is already too strongly involved.

While working with depressed people the therapist has to emphasise security, structure, and learning. The principle of the therapist's approach is support and appreciation of the effort more than frustration, because depressed people frustrate themselves permanently (Roubal, 2007). During therapy patients first learn how to accept support from their surroundings and then they create a system of self-support by themselves. The work centres around a primary task of creating a safe environment, a safe relational field, in which the patient's self-healing powers can be activated.

The therapist accommodates to the actual capacity of the patient. If the patient is experiencing a severe depression, then the most important thing is just to be present and available with hope. The therapist supports the client to hold a distance from the actual experience, to articulate some thinking about it. Later, when the patient is not totally overwhelmed by the depressive experience, $\mathrm{s} / \mathrm{he}$ might have the capacity to explore the meaning of the depressive experience within the context of his life and relationships.

Safeguarding the memory of the future is an important

6 There is a lack of research studies in Gestalt therapy of depression. It seems that the effectiveness of Gestalt therapy is comparable with other therapeutic methods, for example with Cognitive Behavioural therapy (Rosner et al., 1999; Beutler et al., 1991). The effect of a therapy based on a supportive therapeutic relationship may be increased by the use of specific interventions focused on emotions in ways that are used in Gestalt therapy (Greenberg \& Watson, 1998). Greenberg presents the evidence base for emotion-focused therapy (EFT), which he describes as an integration of Gestalt therapy and Person Centered approach. In three separate trials a manualized form of EFT for depression was found to be as effective, or more effective, than a purely relational empathic treatment and a cognitivebehavioral treatment. EFT was more effective in reducing interpersonal problems than both, and promoted more change in symptoms. EFT was also highly effective in preventing relapse (Greenberg \& Watson, 2005). Other research indicates the Gestalt approach is especially effective in the therapies of internalizing patients who deal with depression in intropunitive ways (Beutler et al., 1991). 
therapeutic task. The therapist must pay special attention to making sure that the therapeutic conversation always leaves open chinks through which future possibilities can cast light. If the patient says "I can see no future - only blackness» the therapist can reformulate the statement in order to imply a broader horizon in which the future can be present (e.g. "just now you can't see beyond the difficult phase you're going through»). In the therapeutic relationship, the therapist is the guardian of hope but also, more radically, of time and space. This is true not only in the course of a single session, but also from session to session, inasmuch as the therapist holds together the threads which are gradually co-constructed as the therapeutic relationship progresses. Therapeutic time and space become loci in which the time and space of experience gradually begin to coagulate once more.

It is important to avoid amplification when describing depressive experiences. The therapist should be very careful in verbalising or reformulating patients' experiences. S/ he should confine and limit them to a specific situational frame, since to exaggerate the phenomena would risk further intensifying the experience which already tends to overflow its boundaries. Inasmuch as depressive experiences appear completely cut off from the patient's life, the therapist's task is first and foremost to reconnect and thus to limit them to traceable experiences and events. For example, to the patient's complaint «I have a terrible weight pressing down on my chest ...», one might respond by asking: "How does your breathing change? Are there moments when the pain seems diminished? Can you let me know how it varies over the course of our session?»

Alternatively, it might be useful to contextualise that which the patient presents in generalised terms, in order to restrict the experience to specific situations. Thus, for example, if the patient says, "I feel empty and devoid of energy» the therapist might ask the following questions: "In which situations do you feel this emptiness more and in which less? When did you feel it most strongly this week? Who was with you and what were you doing?" In short, the therapist should not amplify the patient's interior experiences. $S /$ he does not reinforce retroflection, which only intensify the patient's isolation, but rather brings the experience back to the contact boundary, to the site of re-animation and inter-esse.

In the therapy of depressed people the work with retroflection is very specific. The depressed patient turns against himself the feelings and tendencies which s/he would need to direct at his surroundings - for example anger or criticism. The therapist examines these relational patterns directly in her/his present relationship with the patient. And in this relationship s/he also experiments with new ways of behaving and relating. The therapist's task is to enable the patient, even in the most incremental way, to express the energy which he experiences within himself. It is important to find, highlight and appreciate even the briefest moments during which the patient mobilises her/his energy for an action which leads to interpersonal contact, for example when s/he directly looks into the other's eyes or expresses his own opinion. The therapist points these moments out and then leads the patient to the awareness of the process. How has the patient mobilised her/his energy in that particular moment? What did s/he need to make that possible? The patient can come to an innovative experience: «This little thing is something I coped with. I am not completely incapable of action.» Slowly and gradually s/he finds his own way to confirm himself, to mobilise energy and move to action. S/he learns how to moderate expressions of her/his energy. However, working with retroflection the therapist must be cautious. The patient needs a sufficient self-support first to handle the retroflective impulses that might be released in therapy (e.g. anger).

The depressed person needs to learn how to protect her/himself in ways other than by isolating himself. S/he needs to learn how to direct her/his experience into contact with her/his environment. If we work with retroflection this way we can re-orientate the patient's rigid contact style in the opposite direction; we direct it outside. The contact sequence that was stuck before the action by the retroflection can now continue. In the safe relationship with the therapist the patient relearns the ability of flexible contacting and withdrawing. Later he gradually uses the support of the therapeutic relationship to try out these new abilities in other relationships as well. The goal is to restore the ability of self to creatively adjust according to the present needs of the organism and to establish the ability for fluent and flexible contacting and withdrawing.

The extreme fatigue which often plagues patients suffering from depression is the consequence, not of anything they have actively done, but rather of their detachment from every situation. It does not derive from commitment and effort - it rather takes their place. Depressive fatigue is a paradox. It is at its height in the morning and increases with the patient's inactivity, finding relief in physical effort. For this reason, to use one's physical energies, to move, to tire oneself physically, is a positive experience for individuals suffering from depression. In therapy, we should take every opportunity to spur the patient on from this point of view, also encouraging him/ her to undertake physical activities. This body work can be done in different ways and with different frames. As we have already described, the therapist can seek simply to get the patient moving. S/he may seek to promote an awareness in the patient which will increase the sensory and motor possibilities of his/her body. The therapist supports the patient to make a step from mobilising energy to action. At this point, the patient's body will not just be more mobile and efficient, it will also be more alive, free and creative. Here, the focus will be on the patient's feelings as (s)he moves.

Then there is another approach, which is specific to the Gestalt approach and has as its final aim an exploration of contact phenomena (Frank, 2001). The focus here is on the patient and therapist's feelings as the patient moves (or fails to move) towards or away from the therapist. Work on the patient's bodily experiences is geared towards supporting the journey across the space between patient and therapist. In this case, relational space does not correspond to Euclidean space: a few centimetres of physical distance 
may correspond to light years of relational distance. The overall effect of this work is not only to heighten the individual's awareness of his/her own body. It is also to bring the body into play in the field of contact, improving the individual's competence in encountering and being-withthe other. The end result is not a finely sculpted muscle tone so much as another kind of beauty: that profoundly real yet ephemeral beauty which springs from the moment at which the other is fully, truly encountered:

When memories about her father emerge, Ada is frozen, blocked in her petrified posture. I ask her to move towards me, but it is too much, no energy supports this movement. I ask which part of my body may attract her. After a while she says your cheek〉. I propose she cross the space between us with her hand to reach my cheek. She tries, trembling and slowly she reaches my cheek and suddenly a scream breaks the frozen silence and she starts to cry. It is the first time she can free such a gesture towards a man: until that moment this was an unaccomplished and forgotten gesture cherished for her father.

It is important to highlight again that a Gestalt therapist doesn't see the depressed patient as an object which he researches and to which he applies the therapeutic procedures. The Gestalt therapist works with the relationship between the patient and the therapist. The therapist's task is to ask himself: How do I co-operate in creating the present form of our relationship with the patient? So in the case of the depressive patient the therapist asks: How do I contribute to the fact that the patient who is sitting in front of me is retroflecting and stopping himself before action? How are we depressing together? The therapist then investigates these patterns of relating in the here-and-now therapeutic relationship. Moreover, in this relationship he also experiments with new, unusual ways of behaving and relating.

Accepting the current emotional state of the patient can serve as an example. The therapist takes seriously all of the patient's complaints about low mood, inefficiency, and low self-confidence. But the therapist does not console and does not become resigned. He does not, as far as possible, repeat the reactions the patient has been familiar with in his environment and which again and again supported him in a fixed Gestalt of depression. The patient's family tries to console him: «It's not as bad as you say. Don't worry, everything will be fine soon.» But when the depressed person continues retroflecting and withdrawing from the contact, his close ones resign and send him to a specialist. By doing this, they again strengthen his rigid depressive pattern.

The therapist avoids repeating these patterns. Of course, during the course of therapy s/he will be seduced by the patient to console him or to become resigned. However, based on her/his awareness s/he can liberate her/himself from reacting automatically to the patient and $\mathrm{s} / \mathrm{he}$ creates a free space with the potential for a different way of relating. That enables the patient to step out of the rigid depressive pattern.

The therapist is opening up the possibility of activity through an awareness that client and therapist are together co-creating events as they are unfolding. This having been achieved, the action taken may be something as simple as staying awake, as retaining the capacity to think, or of seeking the support of a third party as the therapist comes near to the depressive abyss. In this way, the therapist doesn't lose hope of eventually reaching the patient, and is able to remain at his/her disposition. This continued ability to hope and to be present (despite the abyssal absence of the other) is the very foundation of therapy when dealing with severe depression.

\section{References}

Akiskal, H.S. (2000). Mood Disorder: Introduction and Overview. In H.I. Kaplan \& B.J. Sadock, Comprehensive Textbook of Psychiatry (pp. 9294-9319). $7^{\text {th }}$ ed. Philadelphia: Lippincott Williams \& Wilkins.

Amendt-Lyon, N. (1999). «Mit Ihnen Schreibe ich heute Geschichte!» . In R. Hutterer-Krisch et al., Neue Entwicklungen in der Integrativen Gestaltherapie. Wiener Beitrage zum Theorie-Praxis-Bezug. Wien: Facultas.

Beutler, L.E. et al. (1991). University of Arizona: Searching for Differential Treatments. Psychotherapy Research: An International Review of Programmatic Studies. Washington D.C.: APA.

Binswanger, L. (1960). Melancholie und Manie. Pfullingen: Neske [ital.: (2006). Melanconia e mania. Torino: Bollati Boringhieri].

Blankenburg, W. (1971). Der Verlust der natürlichen Selbstverständlichkeit. Ein Beitrag zur Psychopathologie symptomarmer Schizophrenien. Stuttgart: Enke [ital.: (1998). La perdita dell'evidenza naturale. Milano: Raffaello Cortina Editore].

Bloom, D. (in preparation). Aspects of depression.

Bonani, M.M. (2009). L'interessamento come terapia. Prospettive sociali e sanitarie, 39(10), 11-15.

Borgna, E. (1988). I conflitti del conoscere. Milano: Feltrinelli.

Borgna, E. (1992). Malinconia. Milano: Feltrinelli.

Borgna, E. (1994). L'immagine psicopatologica e clinica delle depression. In C. Bellantuono et al., La cura dell'infelicità (pp. 29-56). Roma, Napoli: Theoria.

Borgna, E. (2008). Nei luoghi perduti della follia. Milano: Feltrinelli.

Callieri, B. (2001). Quando vince l'ombra. Problemi di psicopatologia clinica. Roma: EUR.

Cavaleri, P. (2007). Vivere con l'altro. Roma: Città Nuova.

Francesetti, G. (2014). Absence is the Bridge Between us. Gestalt Therapy Perspective on Depressive Experiences. Siracusa: HCC Italy Publ.

Francesetti, G. (2019a). The Field Strategy in Clinical Practice: Towards a Theory of Therapeutic Phronesis. In P. Brownell (ed.), Handbook for Theory, Research and Practice in Gestalt Therapy (pp. 268-302). $2^{\text {nd }}$ ed. Newcastle Upon Tyne: Cambridge Scholars Publ.

Francesetti, G. (2019b). A Clinical Exploration of Atmospheres. Towards a Field-based Clinical Practice. In G. Francesetti \& T. Griffero (eds.), Psychopathology and Atmospheres. Neither Inside nor Outside (pp. 35-68). Newcastle Upon Tyne: Cambridge Scholars Publ.

Francesetti, G. \& Gecele, M. (2009). A Gestalt Therapy Perspective on Psychopathology and Diagnosis, The British Gestalt Journal, 18, 2.

Francesetti, G. \& Gecele, M. (2010). La prospettiva della psicoterapia della Gestalt sulla psicopatologia e diagnosi. Quaderni di Gestalt, $23,44$.

Francesetti, G. \& Gecele, M. (2011). L'altro irraggiungibile. La psicoterapia della Gestalt con le esperienze depressive. Milano: FrancoAngeli.

Francesetti, G., Gecele, M. \& Roubal, J. (2013). Gestalt Therapy in Clinical Practice. Siracusa: HCC Italy Publ.

Francesetti, G. \& Roubal, J. (forthcoming). Field Theory in Contemporary Gestalt Therapy. Part 1: Modulating the Therapist's Presence in Clinical Practice. Gestalt Review. 
Frank, R. (2001). Body of Awareness. A Somatic and Developmental Approach to Psychotherapy. Cambridge/MA: Gestalt Press [ital.: (2005). Il corpo consapevole. Milano: FrancoAngeli].

Freud, S. (1925 [1917]). Mourning and Melancholia. Collected Papers, $4,152-170$.

Galimberti, U. (1987). Psichiatria e fenomenologia. Milano: Feltrinelli. Galimberti, U. (2003). Il corpo. Milano: Feltrinelli.

Gozzetti, G. (2008). La tristezza vitale. Fenomenologia e psicopatologia della melanconia. Roma: Giovanni Fioriti.

Greenberg, L. \& Watson, J. (1998). Experiential therapy of depression: differential effects of client-centered relationship conditions and process experiential interventions. Psychotherapy Research, $8(2), 210-224$

Greenberg, L. \& Watson, J. (2005). Emotion-focused Therapy for Depression. Washington D.C.: APA.

Greenberg, L., Watson, J. \& Goldman, R. (1998). Process-Experiential Therapy of Depression. In L. Greenberg, J. Watson \& G. Litaer (eds.), Handbook of Experiential Psychotherapy (pp. 227-248). London: Guilford Press.

Joiner, T.E. jr \& Katz, J. (1999). Contagion of Depressive Symptoms and Mood: Meta-analytic Review and Explanations From Cognitive, Behavioural, and Interpersonal Viewpoints. Clinical Psychology: Science and Practice, 6(2), 149-164.

Kimura, B. (2000). L'entre. Une approche phénoménologique de la shizophrénie. Grénoble: Editions Jérôme Millon.

Kimura, B. (2005). Scritti di psicopatologia fenomenologica. Roma: Giovanni Fioriti.

Maldiney, H. (1991). Penser l'homme et la folie. Grénoble: Editions Jérôme Millon [ital.: (2007). Pensare l'uomo e la follia. Torino: Einaudi].

Melnick, J. \& Nevis, S.M. (1998). Diagnosing in the Here and Now: a Gestalt Therapy Approach, in Handbook of Experiential Psychotherapy: Foundations and Differential Treatment. New York: Guilford.

Minkowski, E. (1933). Le temps vécu: études phénoménologiques et phychopathologiques. Paris: Presses Univ. de France [ital.: (2004). Il tempo vissuto. Torino: Einaudi].

Robine, J.-M. (2011). On the Occasion of an Other. Gouldsboro/ ME: Gestalt Journal Press [ital.: (2011). Il dispiegarsi del sé nel contatto. Milano: FrancoAngeli].

Rosner, R. et al. (1999). Course of Depression in Different Psychotherapies. An Application of Hierarchical Linear Models. Zeitschrift für Klinische Psychologie, 28(2), 112-120.

Rossi Monti, M. (2002). Percorsi di psicopatologia. Milano: FrancoAngeli.

Roubal, J. (2007). Depression. A Gestalt Theoretical Perspective. The British Gestalt Journal, 16(1), 35-43.

Roubal, J. (2010). Oral communication, EAGT Conference, Berlin, Sept. 2010

Salonia, G. (1989). Dal Noi all'Io-Tu: contributo per un teoria evolutiva del contatto. Quaderni di Gestalt, 8/9, 45-54.

Salonia, G. (2001a). Disagio psichico e risorse relazionali. Quaderni di Gestalt, 32/33, 13-22.

Salonia, G. (2001b). Tempo e relazione. L'intenzionalità relazionale come orizzonte ermeneutico della psicoterapia della Gestalt. In M. Spagnuolo Lobb (ed.), La Psicoterapia della Gestalt. Ermeneutica e clinica (pp. 65-85). Milano: FrancoAngeli.

Salonia, G. (2005). Cambiamenti sociali e disagi psichici. Attacchi di panico e postmodernità. In G. Francesetti (ed.), Attacchi di panico e postmodernità. La psicoterapia della Gestalt fra clinica e società (pp. 36-50). Milano: FrancoAngeli.
Salonia, G. (2008). La psicoterapia della Gestalt e il lavoro sul corpo. Per una rilettura del fitness. In S. Vero, Il corpo disabitato. Semiologia, fenomenologia e psicopatologia del fitness (pp. 51-72). Milano: FrancoAngeli.

Salonia, G. (2010). L'anxiety come interruzione nella Gestalt Therapy. In L.D. Regazzo (ed.), Ansia, che fare? Prevenzione farmacoterapia e psicoterapia (pp. 233-254). Padova: CLEUP.

Smith, E. (1985). A Gestalt Therapist's Perspective on Grief. Psychotherapy Patient, 2(1), 65-78.

Spagnuolo Lobb, M. (2001a). From the Epistemology of Self to Clinical Specificity of Gestalt Therapy, in Contact and Relationship in a Field Perspective. Bordeaux: L'Exprimerie.

Spagnuolo Lobb, M. (2001b). La teoria del sé in psicoterapia della Gestalt. In M. Spagnuolo Lobb (ed.), La Psicoterapia della Gestalt. Ermeneutica e clinica (pp. 86-110). Milano FrancoAngeli.

Spagnuolo Lobb, M. (ed.). (2005). Gestalt-thérapie avec des patients sévèrement perturbés. Bordeaux: L'Exprimerie.

Spagnuolo Lobb, M. (2007). L'adattamento creativo nella follia: un modello terapeutico gestaltico per pazienti gravi. In M. Spagnuolo Lobb \& N. Amendt-Lyon (eds.), Il permesso di creare. L'arte della psicoterapia della Gestalt (pp. 338-360). Milano: FrancoAngeli.

Staemmler, F. (2004). Cultiver l'incertitude. Bordeaux: L'Exprimerie.

Stanghellini, G. (2006). Psicopatologia del senso commune. Milano: Raffaello Cortina Editore.

Van Baalen, D. (2010). Gestalt Therapy and Bipolar Disorder. Gestalt Review, 14(1), 71-88.

Vázquez Bandín, C. (2005). Espérame en el cielo. In A. Martín \& C. Vázquez Bandín, Cuando me encuentro con el Capitán Grafio ... (no) me engancho (pp. 62-87). Bilbao: Ed. Desclée de Brouwer.

\section{The Authors}

Gianni Francesetti, Dr., is a Psychiatrist, Gestalt therapist, Adjunct Professor of Phenomenological and Existential Approach, Dep. of Psychology, University of Torino (Italy), International Trainer and Supervisor. He is President of the IPsiG - International Institute for Gestalt Therapy and Psychopathology and of Poiesis - Gestalt Therapy Clinical Centre of Torino.

Jan Roubal, Dr., is an Associate Professor at Masaryk University in Brno, Czech Republic, where he also works in the Centre for Psychotherapy Research. He works as Psychotherapist and Psychiatrist. He founded the Training in Psychotherapy Integration and the training Gestalt Studia in the Czech Republic. He also works as a Psychotherapy Trainer and Supervisor internationally.

\section{Contact}

Gianni Francesetti

E-Mail: gianni.francesetti@gmail.com

Jan Roubal

E-Mail: jan.roubal.cz@gmail.com 